\title{
IDENTIFIKASI PARABEN PADA PRODUK PERAWATAN TUBUH
}

\author{
Nur Qadri Rasyid ${ }^{1)}$ Muawanah ${ }^{1)}$ \\ 1)Akademi Analis Kesehatan Muhammadiyah Makassar \\ Alamat Korespondensi: nqadrir@gmail.com
}

\begin{abstract}
Abstrak
Ester alkil dari asam p-hidroksibenzoat (paraben) digunakan secara luas sebagai agen antimikroba, dengan aktivitas antimikroba meningkat seiring dengan meningkatnya panjang rantai alkil. Senyawa ini digunakan secara luas dalam ribuan produk perawatan tubuh yang digunakan setiap hari untuk mencegah tumbuhnya bakteri pada produk tersebut. Penelitian yang dilakukan oleh Barr et al., (2011) mengkofirmasi mengenai toksisitas paraben yang dapat diserap secara sistematik pada manusia dan ditemukan paraben utuh di empat lokasi di seluruh bagian payudara pada penderita kanker payudara primer di Inggris antara tahun 2005 dan 2008. Secara keseluruhan jenis paraben yang tertinggi yaitu n-propil paraben dan metilparaben dan tingkat yang lebih rendah untuk n-butilparaben, etilparaben dan isobutilparaben. Pada penelitian ini sumber paraben tidak dapat diindentifikasi. Tetapi, paraben diukur dalam 7/40 pasien melaporkan pernah menggunakan kosmetik pada bagian ketiak selama hidup mereka. Di Indonesia penggunaan paraben dalam produk perawatan tubuh masih digunakan untuk memperpajang masa pakai produk. Oleh karena itu penelitian awal dibutuhkan untuk mengidentifikasi adanya paraben yang digunakan dalam beberapa produk perawatan tubuh sehingga dapat digunakan sebagai acuan untuk penelitian lanjutan ke tingkat toksisitas paraben terhadap pajanan dalam tubuh manusia. Metode identifikasi paraben yang digunakan adalah uji warna pada 20 jenis produk perawatan tubuh terkenal yang beredar di Indonesia. Hasil identifikasi paraben pada 20 sampel produk perawatan tubuh diperoleh sekitar 75\% mengandung paraben. Nilai ini menunjukkan angka yang tinggi mengingat produk perawatan tubuh yang digunakan konsumen sekitar 1-5 produk yang berbeda setiap harinya. Hal ini dapat memicu penyerapan paraben secara dermal.
\end{abstract}

Kata Kunci: Paraben, Perawatan tubuh, Toksisitas, Uji warna

\section{PENDAHULUAN}

Produk-produk perawatan tubuh adalah bagian dari kebutuhan sehari-hari yang tidak terpisahkan dari gaya hidup modern. Produk tersebut memiliki banyak manfaat untuk memperindah, meremajakan dan bahkan menyehatkan rambut dan kulit. Namun, sebagian produk tersebut mengandung bahanbahan kimia berbahaya yang pada pemakaian kontinyu akhirnya dapat menimbulkan gangguan yang serius pada kondisi kesehatan pemakainya. Meski pada umumnya gangguan kesehatan ini dapat muncul dan merupakan efek jangka panjang setelah pemakaian produk kontinyu. Mengenali dan melihat jenis kandungan dan komposisi produk perawatan tubuh yang dibeli dan digunakan setiap hari, diharapkan tidak timbul dampak negatif dari penggunaan produk tersebut. Salah satu bahan kimia sintetik yang digunakan pada banyak produk perawatan tubuh adalah Paraben.

Ester alkil dari asam phidroksibenzoat (paraben) digunakan secara luas sebagai agen antimikroba, dengan aktivitas antimikroba meningkat seiring dengan meningkatnya panjang rantai alkil dari metil ke n-butil (Darbre et al., 2004). Oleh karena efektifitas antimikroba dalam senyawa paraben, maka senyawa ini digunakan secara luas dalam ribuan produk perawatan tubuh yang digunakan setiap hari untuk mencegah tumbuhnya bakteri. Bahan kimia ini banyak ditemukan di kosmetik, shampoo, lotion, sabun, dan produk perawatan lainnya dalam bentuk metilparaben, etilparaben, butilparaben, propil-paraben dan biasanya juga digunakan lebih dari satu jenis paraben 
atau di kombinasi dengan bahan pengawet

kimia lainnya. Dalam kosmetik, paraben diijinkan dalam konsentrasi hingga $1 \%$ (Elder, 1984).

Paraben pertama kali disetujui untuk digunakan dalam produk kosmetik pada tahun 1984 ketika Cosmetic Ingredient Review (CIR) menyatakan bahwa paraben aman digunakan. Pada tahun 2003 dan 2005 CIR meninjau ulang parabens yang digunakan dalam kosmetik dan menyatakan bahwa parabens aman digunakan. Selanjutnya, pada tahun 2004 diperoleh ester alkil dari paraben utuh dari jaringan tumor payudara manusia. Hal ini memicu perdebatan international mengenai penggunaan paraben yang meskipun dianggap memiliki toksisitas rendah. Namun, studi dari tahun 1998 dan seterusnya telah mulai menunjukkan paraben memiliki sifat estrogenik (Darbre et al., 2004), dan estrogen yang dikenal memainkan peran sentral dalam pengembangan, pertumbuhan dan perkembangan kanker payudara (Miller, 1996). Paraben memiliki koefisien partisi minyak/air yang tinggi dan kelarutan air berkurang dengan meningkatnya panjang rantai ester. Oleh karena itu, jika paraben utuh masuk ke dalam tubuh manusia, maka paraben kemungkinan dapat terakumulasi dalam komponen lemak dari jaringan tubuh. Meskipun sumber paraben tidak dapat diidentifikasi dalam jaringan payudara manusia, Darbre dan Harvey menyarankan bahwa penyerapan tingkat rendah dermal dari produk perawatan pribadi diterapkan pada daerah payudara dalam jangka panjang mungkin telah berkontribusi dalam perkembangan kanker payudara (Darbre et al., 2004).

Penelitian lain yang mengkofirmasi bahwa paraben dapat diserap secara sistematik pada manusia sebagai ester utuh dari aplikasi topikal paraben dalam produk perawatan tubuh, menunjukkan bahwa terdapat ester paraben dalam darah yang diukur kurang dari 1 jam setelah aplikasi dermal. Kemudian studi di Norwegia melaporkan bahwa ester paraben dapat diukur di lebih dari $60 \%$ dari sampel darah yang diambil dari populasi umum dan bahwa terdapat hubungan yang signifikan antara konsentrasi paraben dalam darah dan penggunaan produk perawatan tubuh.

Penelitian yang dilakukan oleh Barr et al. (2011) menunjukkan bahwa terdapat ester asam p-hidroksibenzoat (paraben) yang ditemukan di empat lokasi di seluruh bagian payudara pada penderita kanker payudara primer di Inggris antara tahun 2005 dan 2008. Secara keseluruhan jenis paraben yang tertinggi yaitu n-propil paraben dan metilparaben dan tingkat yang lebih rendah untuk n-butilparaben, etilparaben dan isobutilparaben. Pada penelitian ini sumber paraben tidak dapat diindentifikasi. Tetapi, paraben diukur dalam 7/40 pasien melaporkan pernah menggunakan kosmetik pada bagian ketiak selama hidup mereka.

Di Indonesia kebutuhan penggunaan paraben dalam produk perawatan tubuh masih digunakan untuk memperpajang masa pakai produk. Kebutuhan akan bahan kimia ini sebagai antimikrobial kemungkinan masih terdapat di beberapa produk perawatan pada krim wajah, lotion, sabun mandi, sampo dan beberapa produk kosmetik lain yang memiliki komposisi berupa propil paraben, metil paraben, etil paraben, butil paraben maupun yang dalam bentuk campuran.

Oleh karena itu dibutuhkan penelitian awal untuk mengidentifikasi adanya paraben yang digunakan dalam beberapa produk perawatan tubuh sehingga dapat digunakan sebagai acuan untuk penelitian lanjutan ke tingkat toksisitas paraben terhadap pajanan dalam tubuh manusia

\section{METODE PENELITIAN}

\section{Alat dan Bahan}

Alat-alat yang digunakan adalah pipet tetes, tabung reaksi, cawan porselen, kertas saring, rak tabung, dan penjepit tabung.

Bahan-bahan yang digunakan adalah $\mathrm{FeCl}_{3}, \mathrm{AgNO}_{3}$, Fehling, $\mathrm{HNO}_{3}$, Aquades, Metanol.

Prosedur Penelitian

$\begin{array}{llr}\text { Ekstraksi } & \text { paraben dari } & \begin{array}{c}\text { produk } \\ \text { tubuh }\end{array}\end{array}$ 
Sampel di timbang sebanyak 500 mg kemudian dihomogenisasi dengan 5 $\mathrm{ml}$ etanol $50 \%$ hingga larut seluruhnya, Larutan kemudian di saring dengan kertas saring whatmann. Hasil penyaringan digunakan untuk pemeriksaan metil dan propil paraben.

\section{Identifikasi Metil paraben (Nipagin) dengan reaksi warna}

Memasukkan sampel pada tabung reaksi dan menambah $\mathrm{FeCl}_{3}$. Dihasilkan warna ungu coklat jika positif terdapat metil paraben. Memasukkan sampel pada tabung reaksi dan tambah $\mathrm{AgNO}_{3}$. Dihasilkan endapan putih jika positif terdapat metil paraben.

Memasukkan sampel pada tabung reaksi dan tambah $\mathrm{HNO}_{3}$. Dihasilkan warna keruh jika positif terdapat metil paraben.

\section{HASIL PENELITIAN}

Penelitian ini dilaksanakan pada bulan Agustus-September 2015 yang dilakukan di Laboratorium Kimia, Akademi Analis Kesehatan Muhammadiyah Makassar. Total sampel dalam penelitian ini yaitu 20 jenis produk perawatan tubuh berbagai merk yang beredar di Kota Makassar. Sebelum melakukan identifikasi sampel produk perawatan tubuh di ekstraksi dengan menggunakan etanol 50\%. Pada Tabel 1 menunjukkan hasil identikasi metil paraben.

Tabel 1. Identifikasi metil paraben dengan reaksi warna

\begin{tabular}{cc}
\hline Sampel & Hasil Identifikasi \\
\hline A & Positif \\
B & Positif \\
C & Positif \\
D & Positif \\
E & Positif \\
F & Negatif \\
G & Positif \\
H & Positif \\
I & Positif \\
J & Positif \\
K & Positif \\
L & Negatif \\
M & Positif \\
N & Positif \\
O & Positif \\
P & Positif \\
Q & Positif \\
\hline
\end{tabular}

$$
\begin{array}{ll}
\mathrm{R} & \text { Negatif } \\
\mathrm{S} & \text { Negatif } \\
\mathrm{T} & \text { Positif }
\end{array}
$$

Tabel 2. Persentase metil paraben pada Produk Perawatan Tubuh

\begin{tabular}{cc}
\hline $\begin{array}{c}\text { Metil Paraben } \\
\text { Produk }\end{array}$ & Jumlah \\
\hline Negatif & $4(20 \%)$ \\
Positif & $16(80 \%)$ \\
\hline Jumlah & $20(100 \%)$ \\
\hline
\end{tabular}

Hasil pemeriksaan dari 20 sampel produk perawatan tubuh ditemukan $80 \%$ positif mengandung paraben.

\section{PEMBAHASAN}

Berbagai produk perawatan tubuh seperti sabun mandi, sampo, deodorant, hand body lotion yang menggunakan paraben sebagai antimikroba dan bahan pengawet masih beredar luas di Indonesia. Dalam beberapa penelitian paraben dalam produk perawatan tubuh dapat menimbulkan gangguan hormonal yang berefek negatif, yaitu kanker payudara dan toksisitas terhadap organ-organ reproduksi. Paraben dapat meniru estrogen dan berikatan dengan reseptor estrogen di dalam sel tubuh. Selain itu, Paraben dapat meningkatkan ekspresi gen yang biasanya diatur oleh estradiol (bentuk alami dari estrogen); gen ini yang menyebabkan sel-sel payudara tumbuh dan berkembang. Selain itu Paraben juga berhubungan dengan kanker, gangguan reproduksi, immunotoxicity, neurotoxicity dan iritasi kulit. Berbagai dampak yang dapat ditimbulkan dengan penambahan paraben pada produk perawatan tubuh menimbulkan berbagai spekulasi tentang penggunaan bahan tersebut untuk meningkatkan mutu produk. Penelitian ini merupakan tahap awal untuk menguji tingkat toksisitas paraben pada beberapa produk perawatan tubuh. Tujuan penelitian ini untuk mengidentiffikasi kandungan metil paraben dalam berbagai produk perawatan tubuh yang beredar di pasaran secara kimia dengan reaksi warna.

Langkah pertama yang dilakukan adalah mengekstraksi paraben dalam sampel dengan cara melarutkan sampel dalam metanol 50\%, hasil ekstraksi yang diperoleh kemudian dilakukan identifikasi 
metil paraben. Identifikasi metil paraben menunjukkan hasil positif jika pada sampel yang ditambahkan $\mathrm{HNO}_{3}$ menunjukkan larutan yang keruh sedangkan sampel jika ditambahkan dengan $\mathrm{AgNO}_{3}$ akan terbentuk endapan. Endapan ini terbentuk karena Ag terikat pada gugus ester yang terdapat pada metil paraben, seperti yang terlihat pada persamaan reaksi berikut ini :

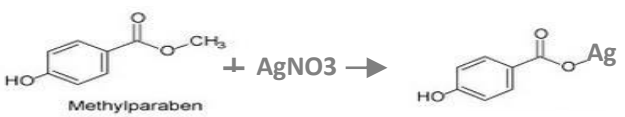

\section{Gambar 1. Persamaan Reaksi Methylparaben dengan $\mathrm{AgNO}_{3}$}

Pada Tabel 1 menunjukkan bahwa dari 20 sampel produk perawatan tubuh yang diidentifikasi terdapat $75 \%$ produk yang mengandung metil paraben. Nilai ini menunjukkan angka yang tinggi mengingat produk perawatan tubuh yang digunakan konsumen sekitar 1-5 produk yang berbeda setiap harinya. Hal ini dapat memicu penyerapan paraben secara dermal. Berdasarka data Scientific Committee on Consumer Safety (SCCS) telah merekomendasikan untuk mengurangi konsentrasi maksimum paraben dalam kosmetik dari $0,4 \%$ menjadi $0,19 \%$. Konsentrasi ini merupakan konsentrasi untuk satu produk perawatan tubuh. Namun, konsumen yang notabennya adalah wanita menggunakan lebih dari satu produk perawatan tubuh sehingga kemungkinan untuk terpajan paraben perhari lebih besar.

\section{KESIMPULAN}

Dari hasil penelitian yang dilakukan maka dapat disimpulkan :

1. Identifikasi paraben pada 20 sampel produk perawatan tubuh diperoleh sekitar $75 \%$ mengandung paraben.

2. Penambahan paraben pada produk perawatan tubuh dapat memicu penyerapan paraben secara dermal.

\section{SARAN}

1. Pengujian secara kualitatif dilakukan dengan spektofotemtri UV-Vis

2. Dilakukan pengujian secara kuantitatif dengan menggunakan Kromatografi Cair Kinerja Tinggi (KCKT).

\section{DAFTAR PUSTAKA}

Boberg J, Taxvig C, Christiansen S, Hass U. 2010. Possible endocrine disrupting effects of parabens and their metabolites. Reprod Toxicol; 30(2):301-12.

Barr L, Metaxas G, Harbach CAJ, Savoy LA, Darbre PD. 2011. Measurement of paraben concentrations in human breast tissue at serial locations across the breast from axilla to sternum. J. Appl. Toxicol.

Charles AK, Darbre PD. 2013. Combinations of parabens at concentrations measured in human breast tissue can increase proliferation of MCF-7 human breast cancer cells. J Appl Toxicol.

Cowan-Ellsberry CE, Robison SH. 2009. Refining aggregate exposure: example using parabens. Regul Toxicol Pharmacol; 55(3):321-9.

Darbre PD, Aljarrah A, Miller WR, Coldham NG, Sauer MJ, Pope GS. 2004. Concentrations of parabens in human breast tumours. J Appl Toxicol. 24(1):5-13.

Darbre PD, Harvey PW. 2008. Paraben esters: review of recent studies of endocrine toxicity, absorption, esterase and human exposure, and discussion of potential human health risks. J Appl Toxicol; 28(5):561-78.

Elder RL. 1984. Final report on the safety assessment of methylparaben, ethylparaben, propylperaben and butylparaben. J. Ame. Coll. Toxicol. 3: 147-209.

Hoberman AM, Schreur DK, Leazer T, Daston GP, Carthew P, Re T, et al. 2008. Lack of effect of butylparaben and methylparaben on the reproductive system in male rats. Birth Defects Res B Dev Reprod Toxicol; 83(2):123-33.

Miller WR. 1996. Estrogen and Breast Cancer. Chapman and Hall: London.

Soni MG, Carabin IG, Burdock GA. 2005. Safety assessment of esters of p-hydroxybenzoic acid (parabens). 
Food Chem Toxicol; 43(7):985-

1015.

Sandanger TM, Huber S, Moe MK, Braathen T, Leknes H, Lund E. 2011. Plasma concentrations of parabens in postmenopausal women and self-reported use of personal care products: the NOWAC postgenome study. J Expo Sci Environ Epidemiol; 21(6):595600.

Scientific Committee on Consumer Safety (SCCS). 2011. Clarification on Opinion SCCS/1348/10 in the light of the Danish clause of safeguard banning the use of parabens in cosmetic products intended for children under three years of age. Brussels, Belgium: The European Commission (EC). Report No 1446. 